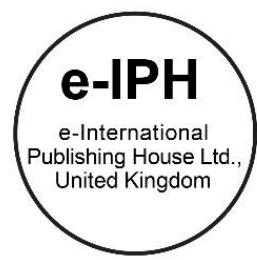

\title{
The Distinction of Personal Factors on Perception of Environmental Problems: Thai adolescence
}

\author{
Chanon Tunprawat ${ }^{1 *}$, Yanin Rugwongwan ${ }^{2}$, Wichitra Singhirunnusorn ${ }^{3}$ \\ ${ }^{1}$ Arch D. Student, Faculty of Architecture, King Mongkut's Institute of Technology Ladkrabang (KMITL), 10520, Thailand \\ ${ }_{2}^{2}$ Asst. Prof. Ph.D. program in school of Interior Architecture, Faculty of Architecture, King Mongkut's Institute of Technology Ladkrabang (KMITL), 10520, Thailand \\ ${ }^{3}$ Ph.D., Lecturer, Faculty of Environment and Resource Studies, Mahasarakham University (MSU), 44150, Thailand \\ nonimailing@mail.com \\ Tel:+66819083970
}

\begin{abstract}
This research was to study the environmental perception of the difference of personal factors. Sixteen environmental problem issues were used to study. The research instrument used in this study were measurement of perceiving levels using Likert scale 1-5 questionnaires. The samples were 120 undergraduate students in Rajamangala University of Technology Phra Nakhon, Bangkok, Thailand. The sampling was nonprobability sampling, the statistical analysis was T-test and analysis of variance (ANOVA). The research finding found that the distinction between personal factors affect the level impact of perception of environmental problems issues on statically significant.
\end{abstract}

Keywords: Environmental Problem; Perception; Personal Factor

eISSN: 2398-4287@ 2017. The Authors. Published for AMER ABRA by e-International Publishing House, Ltd., UK. This is an open access article under the CC BYNCND license (http://creativecommons.org/licenses/by-nc-nd/4.0/). Peer-review under responsibility of AMER (Association of Malaysian Environment-Behaviour Researchers), ABRA (Association of Behavioural Researchers on Asians) and cE-Bs (Centre for Environment-Behaviour Studies), Faculty of Architecture, Planning \& Surveying, Universiti Teknologi MARA, Malaysia.

https://doi.org/10.21834/e-bpj.v2i6.976

\subsection{Introduction}

The study of environmental behaviour is important for an understanding of human actions on the environment. That is to lead to the creation of methods for reducing the impact on the environment by humans. The occurrence of the behaviours may be either intentional or unintentional maybe it comes from the ignorance that what affects the environment. However, the action occurs in various ways. It should create a way to improve the behaviour to be appropriate to reduce environmental problems that affect humans and organisms, in the long run, creating a better quality of life.

Perception is a first process of human behaviour. The action is to receive information in an environment leads to consider and decision-making process. Various information around a human in an environment but human will select to receive some information that they are interested and critical to their benefit or high feeling impact.

Environmental problems are a crisis (Yusof and Jamaludin, 2015) that impacts either direct or indirect way of life. The effects of the problem may be massive or diminutive it can affect to human feeling and lead to feeling anxious. Environmental concern is a high correlation with behaviour (Iversen and Rundmo, 2002)

This study investigated the perceptions of personal factors, according to historical research data, found that individual factors affect environmental behaviour in various aspects (Krajhanzl, 2010) The purpose of the research is 1) study the individual factors that affect the differences on perception of environmental problems and 2) to explore the direction of environmental perception in human factors.

eISSN: 2398-4287O 2017. The Authors. Published for AMER ABRA by e-International Publishing House, Ltd., UK. This is an open access article under the CC BYNCND license (http://creativecommons.org/licenses/by-nc-nd/4.0/). Peer-review under responsibility of AMER (Association of Malaysian Environment-Behaviour Researchers), ABRA (Association of Behavioural Researchers on Asians) and cE-Bs (Centre for Environment-Behaviour Studies), Faculty of Architecture, Planning \& Surveying, Universiti Teknologi MARA, Malaysia.

https://doi.org/10.21834/e-bpj.v2i6.976 


\subsection{Literature Review}

Environmental behavioral education is based on behavioral theory, which has two forms of behavior: 1. covert behavior, a behaviour that can be observed or responded to by persons acting in the form of actions such as walking, running and 2.overt behavior, It is not observable behavior but it is an internal process that leads to external behaviors such as opinions, feelings. Perception is covert behavior that leads to consideration in action or expression.

\subsection{Personal factors and environmental perception}

Personality is an important factor in the study of environmental behaviour (Abraham and Rufaedah, 2013) In the past, Demographics characteristics have been studied about environmental behaviours and perceptions. In this study, the following factors are expected to affect the perception of environmental problems.

- Gender

Some studies on environmental behaviour found that gender influences on environmental behaviours, such as in Lee's study (Lee, 2009), found that females had a higher level of attitudes, concerns, and environmental responsibilities than males. It is consistent with Kollmuss and Agyeman's study (Kollmuss and Agyeman, 2010), who found that women had less environmental knowledge than men but had a greater sense of awareness.

- Age

Age refers to the length of a person's life. People with long lifetimes accumulate a lot of knowledge and experience. Age differences are a factor influencing environmental behaviour. (Gifford and Nilsson 2014) (Wichitra, Kidanun \& Warapon, 2012)

- Income

Income levels affect living conditions, especially in urban areas. Low-income people will have to pay attention to spending in all sectors, such as energy expenditure, shopping. The income level is expected to affect the environmental behaviour both directly and indirectly.

- Hometown

The lifestyle of a person is relevant and bound to the environment. Different conditions exert a significant influence on human behaviour. People living in a natural environment have a way of life that ties to trees or animals. The former residence will show past experiences which may affect the nature of behaviour and environmental perception.

- Characteristics of accommodation

At present, the style of living is more diversity. Residence style is a measure of living conditions and represents economic status and patterns of energy and natural resources. In this study, there are three different types of energy differentiates:

- Single house has the characteristics that residents can control, manage all their home energy usage.

- Condominium or Apartment, the apartment unit is characterized by its residents being able to control their energy usage. Public area must be managed together.

- Home offices are used for both residential and commercial purposes.

- Responsibility for energy costs

In housing, energy and resources such as electricity, water, fuel, who responsible for the charge must be informed of the use and the cost. This may affect environmental behaviour (Hines et al., 1986).

- Residential area

The lifestyle of a person is bound to the area, will have different environmental problems. People living in urban areas are more affected by urban problems than those living in rural areas, leading to differences in perceptions and environmental behaviours. On the other hand, people living in the countryside have different environmental problems. In this research, we want to test the difference in perception of environmental problems, whether they are at different levels or not.

\subsection{Environmental perception and behaviour}

Perception is a psychological process that interprets a person's stimuli in the sensory environment. The stimuli that come into contact are both visible and invisible, Tangible and intangible. Gibson has provided an interpretation of the perception (Gibson, 1950) that the individual is exposed to the environment, and lead to a link to information that is self-contained. Kollmuss and Agyeman (2010) has expanded further in that environment will be vastly different, and personal information will only receive the information they are interested (selective) and is beneficial to themselves. The emergence of the external behaviour is related to the behaviour of internal perception which is regarded as the first procedure within human behaviour. Perception causes knowledge, learning, and emotional processes that lead to behavioural trends. Environmental action is related to the perception process if the person receives adequate information, leads to knowledge. The information that affects the feel very much affects the thinking and decision-making. Environmental issues that people have probably been affected directly or indirectly can recognise that the problem will affect there would be more likely to pay attention and led to the behaviour to find a way to escape by doing something.

\subsection{Environmental problems}

Environmental issues are many and varied, depending on local conditions and the factors that cause them. In the past, environmental issues did not get much attention because they did not affect much. But later, when problems accumulate and are not solved, it has a very intense impact on the present. At the moment, there are significant issues as follows. (Kukreja, 2016) 
- Air Pollution

Weather conditions with contamination levels are higher than normal. Which harms to humans, animals, plants or property. It can happen by nature such as wildfire, volcanic eruptions and human-made such as factory, machinery, vehicle. The emergence of air pollution by humans are violent, dangerous and it tends to occur in the major cities continuously.

- Water Pollution

A condition of water which was contaminated by other substances. There are chemical, oil, sludge, garbage sewage or accumulates by humus and carcasses etc. The primary causes of water pollution come from wastewater and sludge disposal in a production process in a factory that not properly treated, household hazardous waste and wastewater and farming using chemicals which lead to contamination of water resources.

- Soil Pollution

The condition of the soil is contaminated by chemicals or heavy metals, which results in land degradation and accumulation of toxicity. The majorly caused is industrial waste that directly affects the ecosystems in that area.

- Overpopulation

The United Nations reports that the current global population of more than 7.2 billion people (United Nations, 2013) and is likely to continue to increase, which directly affects living resources. According to a survey by The International Energy Agency (EIA, 2013), the use of human resources has never been diminished and is likely to continue from the past. Increasing global population also affects congestion in the major cities and the struggle to hijack resources as well.

- Global Warming

The global average temperatures over the past 100 years have been on the rise (Intergovernmental Panel on Climate Change: IPCC, 2013). The primary cause of global warming is the human activities that emit greenhouse gases such as an industrial operation, burning fuel, livestock etc. The amount of greenhouse gas emissions is a very long time, and thus greenhouse gases accumulate in the atmosphere and contribute to a greenhouse effect. Increasing global temperatures can change ecosystem, seasons and melt of polar ice.

- Natural Resource Depletion

Natural resources have divided into two categories. There is the type used is not exhausted, and the type used is gone. The depletion of used natural resources, such as food in nature. Natural energy will inevitably have a direct impact on human habituation. The main cause of the depletion of natural resources comes from human consumption and human activity.

- Waste Disposal

Human activities create a lot of waste. Both solid and liquid, both in industrial activities and in lifestyle activities, such as garbage, rubbish, packaging waste. The waste accumulates from the past to the present and is likely to continue to rise. Waste disposal is difficult to control.

- Climate Change

Climate change is an environmental problem caused by rising global temperatures. The impact of climate change, the duration of the season is shorter or longer than in the past, someplace that has never snowed. It's turned to snow, or somewhere the weather was high humidity the moisture is thin. This change in climate has become more apparent and has an impact on ecosystems and livelihoods, as well as on human beings.

- Loss of Biodiversity

Multitudinous of creatures are living in this world. The past to the present, some creatures, sorcerers, and spirits disappear from the ecosystem. There are many reasons why human causes are so important to a loss of biodiversity.

- Deforestation

Forests are the source and habitat for many living organisms and are also an important source of human resources. Human exploits the forest abundantly, but on the other hand, it is the destruction of forests, such as forest for city, hunting, cutting trees. Nowadays, the number of forests in the world is rapidly decreasing, which affects creature living and human.

- Ocean Acidification

Sea acidification is a direct impact on coral reefs which are a source of food and shelter for marine animals and marine plants. When coral reefs are destroyed, the marine population in the sea is reduced and fisheries and human food resources are reduced. The cause of the ocean acidification caused by 1) the amount of carbon dioxide in the atmosphere increases rapidly. The cause of acidity alkalinity of the oceans have changed more acidic and 2) the rising temperature causes sea water to absorb less carbon dioxide. From which carbon dioxide is absorbed in the deep sea floating high up near the sea surface, resulting in sea level surface the higher the concentration of $\mathrm{CO}_{2}$ gas.

- Ozone Layer Depletion

Reduction of the ozone layer in the atmosphere has continued and expanded. The ozone layer serves to filter the rays, ultra-violet, which is harmful to the ozone layer is destroyed by the sun's harmful rays would affect the organism is tremendous. Ozone layer depletion is caused by emissions and atmospheric pollutants from industry, deforestation and human activities.

- Urban Sprawl

The world's population continues to increase, thereby causing the expansion of the city to cater to the community. The development of the town must deal with the use of natural resources and manage the environment, such as building roads, bridges, buildings, airports, 
dams, power plants, etc. which things directly affect the environment, and urban sprawl has created other problems, such as pollution, waste, greenhouse gas emissions.

\section{- Acid Rain}

Acid rain contributes to many environmental problems. Acid rain will cause the fertiliser to dissolve in the soil, causing the plant to grow slowly, and when it flows into the water, it will make the water resources unfavourable for living organisms. When acid rain occurs in the city, it can cause problems with the building or may create toxic fumes that damage the respiratory system. Acid rain can occur naturally and can be caused by the burning of fossil fuels that react with water, resulting in acidity.

- Public Health Issues

The current environmental problems pose a risk to the health of humans and animals. Climate change, higher global temperatures, pollution is a threat to the quality of life and human health. Substances that are naturally occurring in nature, causing harm to organisms, infection, and higher temperatures, will be easier for the spread of infectious diseases.

- Genetic Engineering

Genetic engineering is the genetic transformation of food using biotechnology, causing toxins. Plants that have been genetically modified can cause serious environmental problems because of the genes that have been genetically modified to be toxic to wildlife. Another disadvantage is the increased use of toxins to make insect-resistant plants produce organisms that are resistant to antibiotics.

The source of the problem is an issue which directly affects the perception of the person. The source of the problem is a matter which directly affects the perception of the individual; this study has identified the source of the problem areas in the three groups.

- Urban problems

The problem is concentrated in urban areas and come up with a density of population are Air pollution, Water pollution, Soil pollution, Overpopulation, Waste Disposal and Urban Sprawl.

- Rural issues

The problem outside the city is a problem that can be seen and touched in the natural area Include: Natural Resource Depletion, Loss of Biodiversity, Deforestation and Ocean Acidification.

- Independent problems

Problems can be found both in urban and urban areas. The problem was everywhere and expanded to cover all areas Include: Global warming, Climate Change, Ozone Layer Depletion, Acid Rain, Public Health Issues and Genetic Engineering.

In this study, we want to examine the perception of the impact of the problem in each group of problems perceived in the area and outside the problem area.

\subsection{Methodology}

\subsection{Sampling}

The sample in the research was teenagers. Adolescents are considered to be the next generation, which will be affected by long-term environmental problems, access to resources in many ways. Who can perceive information from environmental impacts on current issues and are highly sensitive to information (Knoll, Leung, Foulkes and Blakemore, 2017). The samples selected were 120 undergraduate students from Rajamangala University of Technology Phra Na Khon, Bangkok.

\subsection{Research tools}

The tool is a questionnaire on environmental perception which is divided into 3 parts

- Personal characteristic Question on 7 issues

- The question of Perceiving of 16 environmental issues on 1-5 level of impact

- Environmental perception question in area include: the local level, country area and global scale

3.3 Statistical Analyze

- The descriptive statistics are frequency, percentage, mean and standard deviation.

- The test statistics are independent t-test and Analysis of variance (ANOVA) Post hoc test by Fisher's Least Significant difference (LSD)

\subsection{Result and discussion}

\subsection{Description data}

The sampling is 120 peoples, male and female were similar numbers, 52 males (43.3\%), 68 females (56.7\%). They were aged between 18-23 years old average 19.6 years old. They were undergraduate student $100 \%$ and income between $2000-27000$ baht average income is 6769 baht. The characteristics of accommodation are Single home $43.3 \%$ and Condominium or Apartment $40 \%$. There are people have a hometown in Bangkok $45 \%$ and another $55 \%$. The individual responsible for energy costs is no responsibility $62.5 \%$ pay all and pay for some $37.5 \%$ and that lives in urban areas $61.7 \%$ and $38.3 \%$ in rural areas. 
Table 1. Data description

\begin{tabular}{|c|c|c|c|}
\hline Factors & Variable & Frequency & Percentage \\
\hline \multirow[t]{2}{*}{ 1)Gender } & 1.1) Male & 52 & 43.30 \\
\hline & 1.2) Female & 68 & 56.70 \\
\hline \multirow[t]{2}{*}{ 2)Age } & 2.1) Under 20 years old & 54 & 45.00 \\
\hline & 2.2) Over 20 years old & 66 & 55.00 \\
\hline \multirow[t]{3}{*}{ 3)Income } & 3.1) Under4999 Baht & 32 & 26.70 \\
\hline & 3.2) 5000-9999 Baht & 72 & 60.00 \\
\hline & 3.3) Over 10000 Baht & 16 & 13.30 \\
\hline \multirow[t]{3}{*}{ 4)Characteristics of accommodation } & 4.1) Single home & 52 & 43.30 \\
\hline & 4.2) Apartment or condominium & 48 & 40.00 \\
\hline & 4.3) Home office & 20 & 16.70 \\
\hline Factors & Variable & Frequency & Percentage \\
\hline \multirow[t]{4}{*}{ 5)Hometown } & 5.1) Urban Bangkok & 39 & 32.50 \\
\hline & 5.2) Suburbs Bangkok & 15 & 12.50 \\
\hline & 5.3) Urban in other province & 34 & 28.30 \\
\hline & 5.4) Suburb in other province & 32 & 26.70 \\
\hline \multirow{3}{*}{$\begin{array}{l}\text { 6) Responsibility for energy costs } \\
\text { in home }\end{array}$} & 6.1) Pay for all costs & 12 & 10.00 \\
\hline & 6.2) Pay for some costs & 33 & 27.50 \\
\hline & 6.3) Not pay all & 75 & 62.50 \\
\hline \multirow[t]{2}{*}{ 7) Residential area } & 7.1) Urban area & 74 & 61.70 \\
\hline & 7.2) Rural area & 46 & 38.30 \\
\hline
\end{tabular}

\subsection{Sexual factors with perceived degree of impact on environmental problems}

Gender is a factor that affects the perception of the environment this research requires testing how the factor impacts on the perceived impact of environmental problems.

The results of the perception test did not differ in 12 issues and that were different in 4 issues:1) Deforestation, 2) Ozone Layer Depletion 3) Urban Sprawl and 4) Public Health Issues. The degree of perception, male is higher than females.

Overall, both males and females perceived the impact of the problem to be likely to be in the same direction, with the high average problem group and the low average issue group. On the issue of four perceived issues, it cannot identify why gender differences in perception.

Table 2. Comparative data of Gender factor

\begin{tabular}{|c|c|c|c|c|}
\hline \multirow{2}{*}{ Environmental problems } & \multicolumn{2}{|c|}{ Male } & \multicolumn{2}{|c|}{ Female } \\
\hline & Mean & SD & Mean & SD \\
\hline Air pollution & 3.69 & 0.92 & 3.62 & 0.93 \\
\hline Water pollution & 3.54 & 1.07 & 3.63 & 0.84 \\
\hline Soil pollution & 2.56 & 1.19 & 2.43 & 1.19 \\
\hline Overpopulation & 2.94 & 1.33 & 2.85 & 1.26 \\
\hline Global warming & 4.17 & 0.96 & 4.34 & 0.82 \\
\hline Natural Resource Depletion & 3.88 & 1.29 & 3.60 & 1.39 \\
\hline Waste Disposal & 3.13 & 1.25 & 3.06 & 1.31 \\
\hline Climate Change & 2.90 & 1.18 & 2.99 & 1.21 \\
\hline Loss of Biodiversity & 2.60 & 1.35 & 2.41 & 1.22 \\
\hline Deforestation* ${ }^{*}$ & 4.15 & 1.02 & 3.68 & 1.13 \\
\hline Ocean Acidification & 2.63 & 1.55 & 2.43 & 1.51 \\
\hline Ozone Layer Depletion* & 3.48 & 1.31 & 2.91 & 1.62 \\
\hline Urban Spraw| * & 3.38 & 1.19 & 2.85 & 1.38 \\
\hline Acid Rainant 0.5 & 2.54 & 1.50 & 2.53 & 1.49 \\
\hline Public Health Issues* & 3.35 & 1.20 & 2.71 & 1.26 \\
\hline Genetic Engineering & 2.58 & 1.36 & 2.34 & 1.33 \\
\hline
\end{tabular}

*Significant 0.5

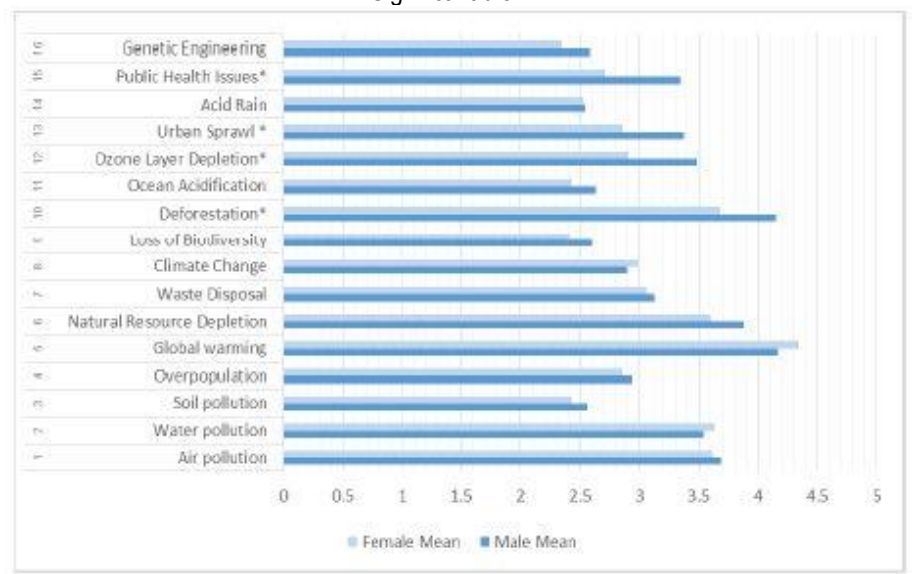

Fig. 1: Comparative data of Gender factor 
4.3 Age factor and level of perception of environmental impacts

The samples are adolescent age range not various which is divided into two groups based on legal age in Thailand that age group one is the lower age group 20 years and the second group is over 20 years old.

There were no significant differences in the perception of 15 issues, and there were two differences in perception are Soil pollution and Urban Sprawl. The study found that degree of perceiving in the age group over 20 years old will have a higher average perception level than those below 20 years of age. Perceived issues are different but no clear reason why age will affect differences in perception.

Table 3. Comparative data of Age factor

\begin{tabular}{lcccr}
\hline \multicolumn{1}{c}{ Environmental Issues } & \multicolumn{2}{c}{ Under 20 } & \multicolumn{2}{c}{ Over 20 } \\
\hline & Mean & S.D. & Mean & S.D. \\
Air pollution & 3.63 & 0.90 & 3.67 & 0.95 \\
Water pollution & 3.52 & 1.09 & 3.65 & 0.81 \\
Soil pollution* & 2.24 & 1.24 & 2.68 & 1.11 \\
Overpopulation & 2.91 & 1.38 & 2.88 & 1.22 \\
Global warming & 4.26 & 0.91 & 4.27 & 0.87 \\
Natural Resource Depletion & 3.70 & 1.42 & 3.74 & 1.30 \\
Waste Disposal & 3.02 & 1.37 & 3.15 & 1.22 \\
Climate Change & 2.72 & 1.14 & 3.14 & 1.21 \\
Loss of Biodiversity & 2.41 & 1.24 & 2.56 & 1.31 \\
Deforestation & 3.72 & 1.22 & 4.02 & 0.98 \\
Ocean Acidification & 2.46 & 1.42 & 2.56 & 1.61 \\
Ozone Layer Depletion & 2.89 & 1.52 & 3.38 & 1.48 \\
Urban Sprawl * & 2.78 & 1.35 & 3.33 & 1.26 \\
Acid Rain & 2.43 & 1.47 & 2.62 & 1.51 \\
Public Health Issues & 2.89 & 1.19 & 3.06 & 1.33 \\
Genetic Engineering & 2.28 & 1.37 & 2.58 & 1.32 \\
\hline
\end{tabular}

*Significant 0.5

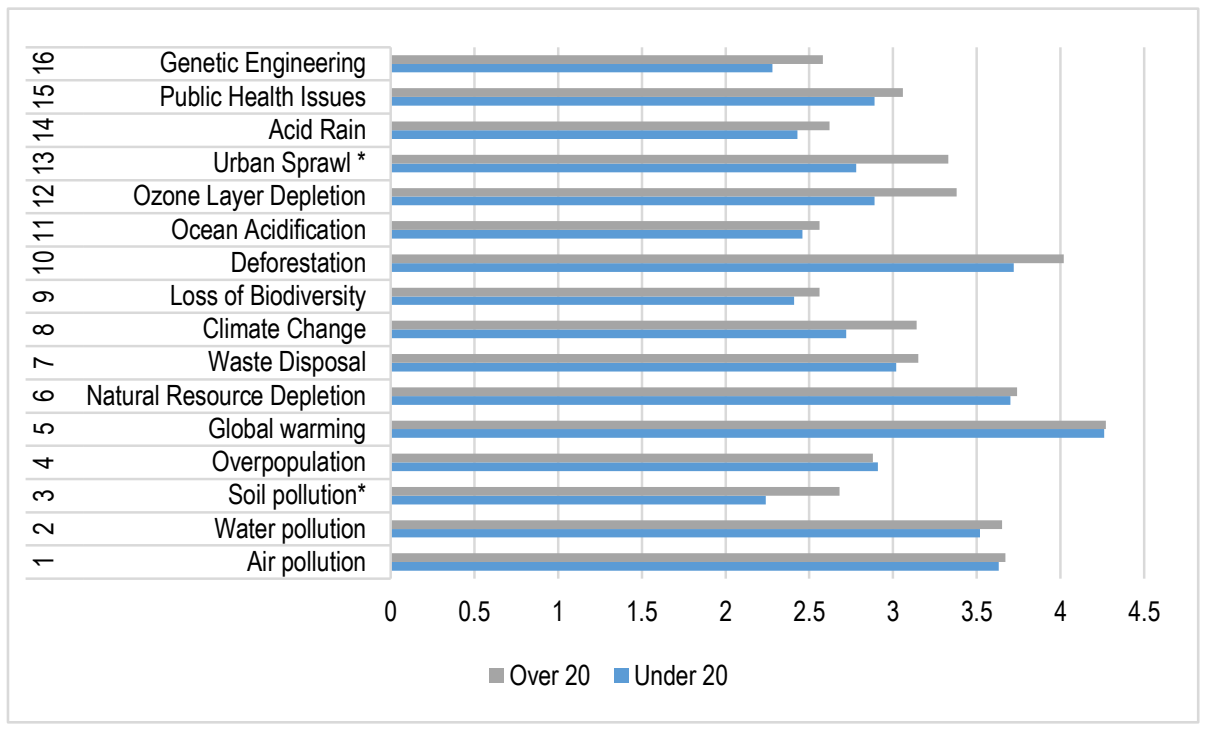

Fig. 2: Comparative data of Age factor

\subsection{Factors of income level and perception of environmental problems}

The data from a sample group shows in overall low-income because they are a student divided into three groups represent income state.

- Low-income group under 4999 Baht

- Middle-income group between 5000-9999 Baht

- High-income group over 10000 Baht

The statistic test showed no significant difference in 3 issues. There is a difference of 13 issues include Water pollution, Soil pollution, Natural Resource Depletion, Waste Disposal, Climate Change, Loss of Biodiversity, Deforestation, Ocean Acidification, Urban Sprawl Acid Rain, Public Health Issues and Genetic Engineering. According to the study, income has a significant impact on environmental perception. High-income groups are significantly higher than middle-income and low-income groups. 
Table 4. Comparative data of Income factor

\begin{tabular}{|c|c|c|c|c|c|c|}
\hline \multirow[t]{2}{*}{ Environmental problems } & \multicolumn{2}{|c|}{$\begin{array}{c}\text { Under } \\
\text { 4,999 Baht }\end{array}$} & \multicolumn{2}{|c|}{$\begin{array}{c}\text { Between } \\
5,000-9,999 \text { Baht }\end{array}$} & \multicolumn{2}{|c|}{$\begin{array}{c}\text { Over } \\
10,000 \text { Baht }\end{array}$} \\
\hline & Mean & S.D. & Mean & S.D. & Mean & S.D. \\
\hline Air pollution & 3.47 & 0.95 & 3.72 & 0.89 & 3.69 & 1.01 \\
\hline Water pollution* & $3.19^{a}$ & 1.09 & $3.71^{b}$ & 0.86 & $3.88^{b}$ & 0.81 \\
\hline Soil pollution* & $1.81^{\mathrm{a}}$ & 1.03 & $2.68^{b}$ & 1.16 & $2.94^{b}$ & 1.12 \\
\hline Overpopulation & 2.53 & 1.32 & 2.99 & 1.25 & 3.19 & 1.33 \\
\hline Global warming & 4.03 & 1.03 & 4.36 & 0.81 & 4.31 & 0.87 \\
\hline Natural Resource Depletion* & $3.13^{a}$ & 1.62 & $3.90^{b}$ & 1.16 & $4.13^{b}$ & 1.26 \\
\hline Waste Disposal* & $2.53^{a}$ & 1.37 & $3.35^{b}$ & 1.16 & $3.06^{a b}$ & 1.34 \\
\hline Climate Change* & $2.72^{\mathrm{a}}$ & 1.25 & $2.90^{\mathrm{a}}$ & 1.13 & $3.63^{b}$ & 1.20 \\
\hline Loss of Biodiversity* & $1.94^{a}$ & 1.10 & $2.60^{b}$ & 1.23 & $3.13^{b}$ & 1.45 \\
\hline Deforestation* & $3.53^{a}$ & 1.24 & $4.07^{b}$ & 0.95 & $3.75^{b}$ & 1.29 \\
\hline Ocean Acidification* & $2.00^{a}$ & 1.32 & $2.57^{a b}$ & 1.53 & $3.31^{b}$ & 1.58 \\
\hline Ozone Layer Depletion* & $2.50^{a}$ & 1.54 & $3.31^{b}$ & 1.46 & $3.81^{b}$ & 1.28 \\
\hline Urban Sprawl * & $2.75^{a}$ & 1.44 & $3.03^{a}$ & 1.27 & $4.00^{b}$ & 0.97 \\
\hline Acid Rain* & $2.03^{a}$ & 1.28 & $2.60^{\mathrm{ab}}$ & 1.49 & $3.25^{b}$ & 1.61 \\
\hline Public Health Issues* & $2.72^{a}$ & 1.28 & $2.94^{a}$ & 1.24 & $3.69^{b}$ & 1.19 \\
\hline Genetic Engineering* & $2.03^{a}$ & 1.23 & $2.47^{a b}$ & 1.35 & $3.13^{b}$ & 1.31 \\
\hline
\end{tabular}

*Significant 0.5

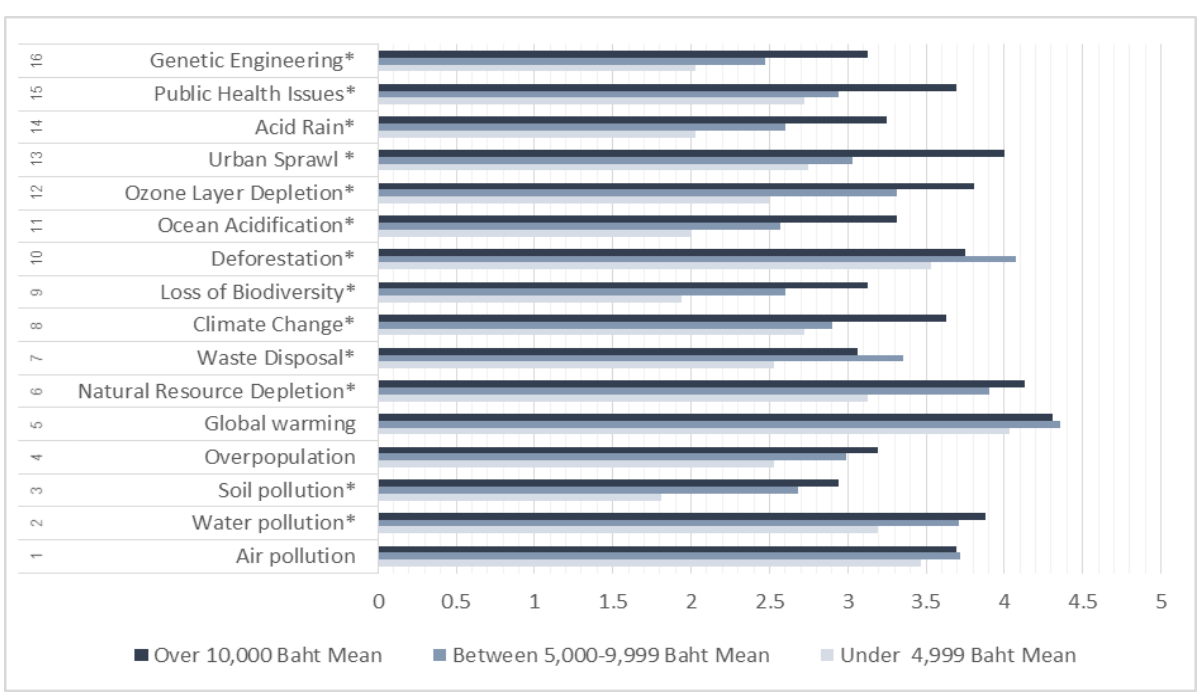

Fig. 3: Comparative data of Income factor

\subsection{Accommodation characteristics of person and perceived environmental problems}

Characteristics of living place are represented of the environment of the people. The difference of position can affect behaviour and feeling of an individual.

The test showed no significant difference in 12 issues but there are differences in four issues: Soil pollution, Waste Disposal, Urban Sprawl and Acid Rain. Overall in distinguishing residential factor the same effect on the perception of environmental problems interesting in Waste disposal and Urban sprawl issues. The finding found the very high average in apartment or apartment occupants group. It is seen that in places where many people live will perceiv the problem of Waste Disposal and Urban Sprawl clearly.

Table 5. Comparative data of Accommodation characteristics factor

\begin{tabular}{|c|c|c|c|c|c|c|}
\hline \multirow[t]{2}{*}{ Environmental Issues } & \multicolumn{2}{|c|}{ Single home } & \multicolumn{2}{|c|}{$\begin{array}{l}\text { Condominium } \\
\text { Apartment }\end{array}$} & \multicolumn{2}{|c|}{ Home office } \\
\hline & Mean & S.D. & Mean & S.D. & Mean & S.D. \\
\hline Air pollution & 3.56 & 0.92 & 3.65 & 0.84 & 3.90 & 1.12 \\
\hline Water pollution & 3.60 & 0.85 & 3.63 & 0.84 & 3.50 & 1.39 \\
\hline \multirow[t]{3}{*}{ Environmental Issues } & \multicolumn{2}{|c|}{ Single home } & \multirow{2}{*}{\multicolumn{2}{|c|}{$\begin{array}{c}\text { Condominium } \\
\text { Apartment }\end{array}$}} & \multicolumn{2}{|c|}{ Home office } \\
\hline & & & & & & \\
\hline & Mean & S.D. & Mean & S.D. & Mean & S.D. \\
\hline Soll pollution" & $2.62^{\mathrm{a}}$ & 1.29 & $2.58^{\mathrm{a}}$ & 1.11 & $1.90^{\circ}$ & 0.97 \\
\hline Overpopulation & 2.87 & 1.30 & 2.88 & 1.23 & 3.00 & 1.45 \\
\hline Global warming & 4.15 & 0.89 & 4.44 & 0.74 & 4.15 & 1.14 \\
\hline
\end{tabular}




\begin{tabular}{lcccccc} 
Natural Resource Depletion & 3.71 & 1.36 & 3.92 & 1.20 & 3.30 & 1.62 \\
Waste Disposal* $^{*}$ & $2.81^{\mathrm{a}}$ & 1.27 & $3.40^{\mathrm{b}}$ & 1.20 & $3.10^{\mathrm{ab}}$ & 1.41 \\
Climate Change & 2.85 & 1.16 & 3.08 & 1.27 & 2.90 & 1.12 \\
Loss of Biodiversity & 2.35 & 1.23 & 2.65 & 1.33 & 2.50 & 1.28 \\
Deforestation & 3.88 & 1.00 & 4.04 & 1.07 & 3.50 & 1.36 \\
Ocean Acidification & 2.65 & 1.47 & 2.52 & 1.65 & 2.15 & 1.35 \\
Ozone Layer Depletion & 3.08 & 1.49 & 3.27 & 1.57 & 3.10 & 1.48 \\
Urban Sprawl & $3.02^{\mathrm{ab}}$ & 1.39 & $3.35^{\mathrm{a}}$ & 1.21 & $2.60^{\mathrm{b}}$ & 1.31 \\
Acid Rain* & $2.48^{\mathrm{ab}}$ & 1.47 & $2.81^{\mathrm{a}}$ & 1.54 & $2.00^{\mathrm{b}}$ & 1.30 \\
Public Health Issues & 3.02 & 1.28 & 3.00 & 1.37 & 2.85 & 1.04 \\
Genetic Engineering & 2.52 & 1.28 & 2.50 & 1.44 & 2.10 & 1.29 \\
\hline
\end{tabular}

*Significant 0.5

a b ab shows different or not different between each group

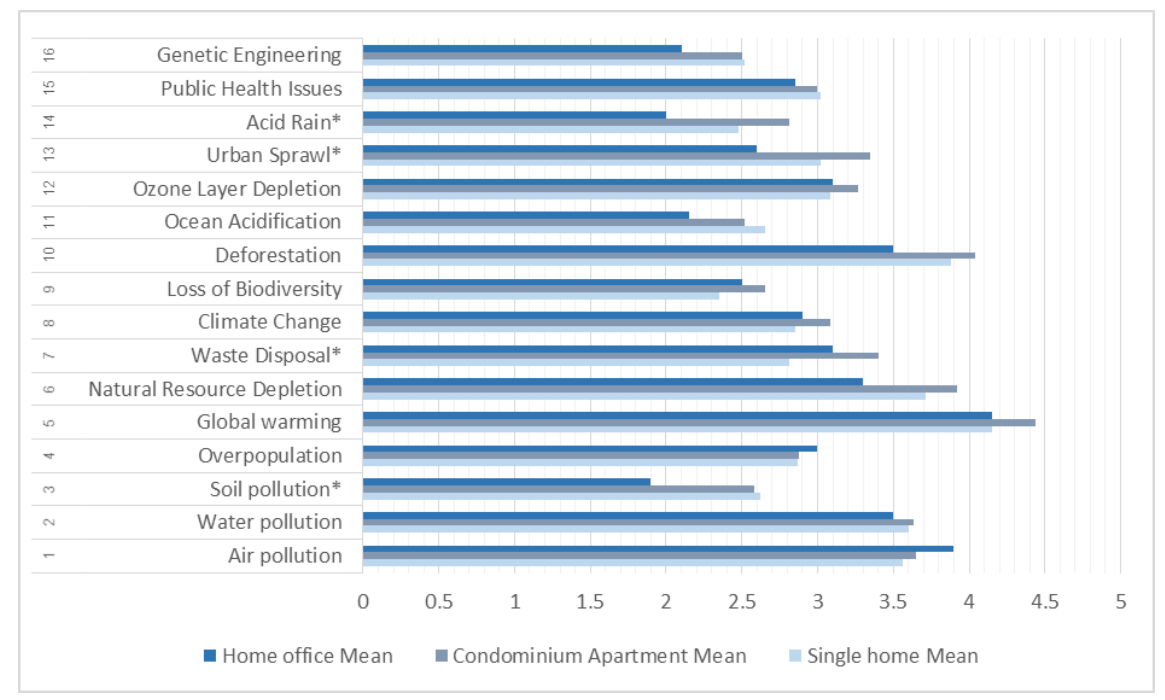

Fig. 4: Comparative data of Accommodation characteristics factor

\subsection{Factors of homeland and perception of environmental issues}

Domicile is a factor that we expect to affect the difference in perception. The study hypothesis is domiciled factors will affect the different perceptions of the impact of environmental issues.

The test found no difference in 13 issues and found differences in 3 issues Deforestation, Acid Rain and Public Health Issues. In general, the domicile factor does not significantly affect the perception of environmental issues, but it is interesting to note. Those who are domiciled outside of the metropolitan area and other non-Bangkok urban areas are more likely to perceive the higher degree of urban Bangkok than those in Bangkok. And in Public Health Issues, Urban Bangkok residents will have lower levels of perceived.

Table 6. Comparative data of hometown factor

\begin{tabular}{|c|c|c|c|c|c|c|c|c|}
\hline \multirow[t]{3}{*}{ Fnvironmental prohlems. } & \multicolumn{2}{|c|}{ Urban. } & \multicolumn{2}{|c|}{ Suburb } & \multicolumn{2}{|c|}{ Urhan in } & \multicolumn{2}{|c|}{ Ruralin } \\
\hline & \multicolumn{2}{|c|}{ Bangkok } & \multicolumn{2}{|c|}{ Bangkok } & \multicolumn{2}{|c|}{ another province } & \multicolumn{2}{|c|}{ another province } \\
\hline & $\begin{array}{c}\text { Mean } \\
369\end{array}$ & $\begin{array}{l}\text { S.D. } \\
0.95\end{array}$ & $\begin{array}{c}\text { Mean } \\
373\end{array}$ & $\begin{array}{l}\text { S.D. } \\
0.88\end{array}$ & $\begin{array}{c}\text { Mean } \\
3.53\end{array}$ & $\begin{array}{l}\text { S.D. } \\
0.96\end{array}$ & $\begin{array}{c}\text { Mean } \\
3.69\end{array}$ & $\begin{array}{l}\text { S.D. } \\
0.90\end{array}$ \\
\hline Water pollution & 3.59 & 0.97 & 3.73 & 0.70 & 3.59 & 0.99 & 3.53 & 1.02 \\
\hline Soil pollution & 2.21 & 1.13 & 2.73 & 1.22 & 2.44 & 1.16 & 2.75 & 1.24 \\
\hline Environmental oroblems & \multicolumn{2}{|c|}{ Urban } & \multicolumn{2}{|c|}{ Suburb } & \multicolumn{2}{|c|}{ Urban in } & \multicolumn{2}{|c|}{ Rural in } \\
\hline & \multicolumn{2}{|c|}{ Bangkok } & \multicolumn{2}{|c|}{ Bangkok } & \multicolumn{2}{|c|}{ another province } & \multicolumn{2}{|c|}{ another province } \\
\hline $\begin{array}{l}\text { Overpopulation } \\
\text { Global warming }\end{array}$ & $\begin{array}{l}\text { Mean } \\
2.79 \\
4.10\end{array}$ & $\begin{array}{l}\text { S.D. } \\
1.30 \\
0.85\end{array}$ & $\begin{array}{c}\text { Mean } \\
3.13 \\
4.00\end{array}$ & $\begin{array}{l}\text { S.D. } \\
1.19 \\
1.13\end{array}$ & $\begin{array}{l}\text { Mean } \\
3.12 \\
4.44\end{array}$ & $\begin{array}{l}\text { S.D. } \\
1.30 \\
0.93\end{array}$ & $\begin{array}{c}\text { Mean } \\
2.66 \\
4.41\end{array}$ & $\begin{array}{l}\text { S.D. } \\
1.31 \\
0.71\end{array}$ \\
\hline Natural Resource Depletion & 3.56 & 1.52 & 3.73 & 1.33 & 3.82 & 1.31 & 3.81 & 1.23 \\
\hline Waste Disposal & 2.92 & 1.36 & 3.20 & 1.32 & 3.24 & 1.33 & 3.09 & 1.15 \\
\hline Climate Change & 2.90 & 1.23 & 3.20 & 1.15 & 3.12 & 1.25 & 2.72 & 1.11 \\
\hline Loss of Biodiversity & 2.28 & 1.32 & 2.87 & 1.46 & 2.59 & 1.30 & 2.47 & 1.11 \\
\hline Deforestation ${ }^{*}$ & $3.62^{\circ}$ & 1.25 & $4.00^{\mathrm{eb}}$ & 0.93 & $3.79=b$ & 1.12 & $4.25^{b}$ & 0.88 \\
\hline Ocean Acidification & 2.21 & 1.34 & 2.80 & 1.82 & 2.59 & 1.56 & 2.69 & 1.55 \\
\hline Ozone Layer Depletion & 2.85 & 1.55 & 3.73 & 1.28 & 3.18 & 1.51 & 3.25 & 1.54 \\
\hline Urban Sprawd & 2.79 & 1.42 & 3.40 & 1.24 & 3.09 & 1.40 & 3.28 & 1.14 \\
\hline Acid Rain* & $2.10=$ & 1.32 & $2.47 \mathrm{st}$ & 1.51 & $2.88^{\circ}$ & 1.57 & $2.72^{\mathrm{ab}}$ & 1.53 \\
\hline Public Health Issues* & $2.64^{\circ}$ & 1.09 & 3.40 & 1.35 & $3.12^{\mathrm{ab}}$ & 125 & $3.06^{a b}$ & 1.41 \\
\hline Genetic Engineering & 2.41 & 1.35 & 2.80 & 1.26 & 2.50 & 1.44 & 2.25 & 1.29 \\
\hline
\end{tabular}

*Significant 0.5

$: b$ shows different or not different between each group 


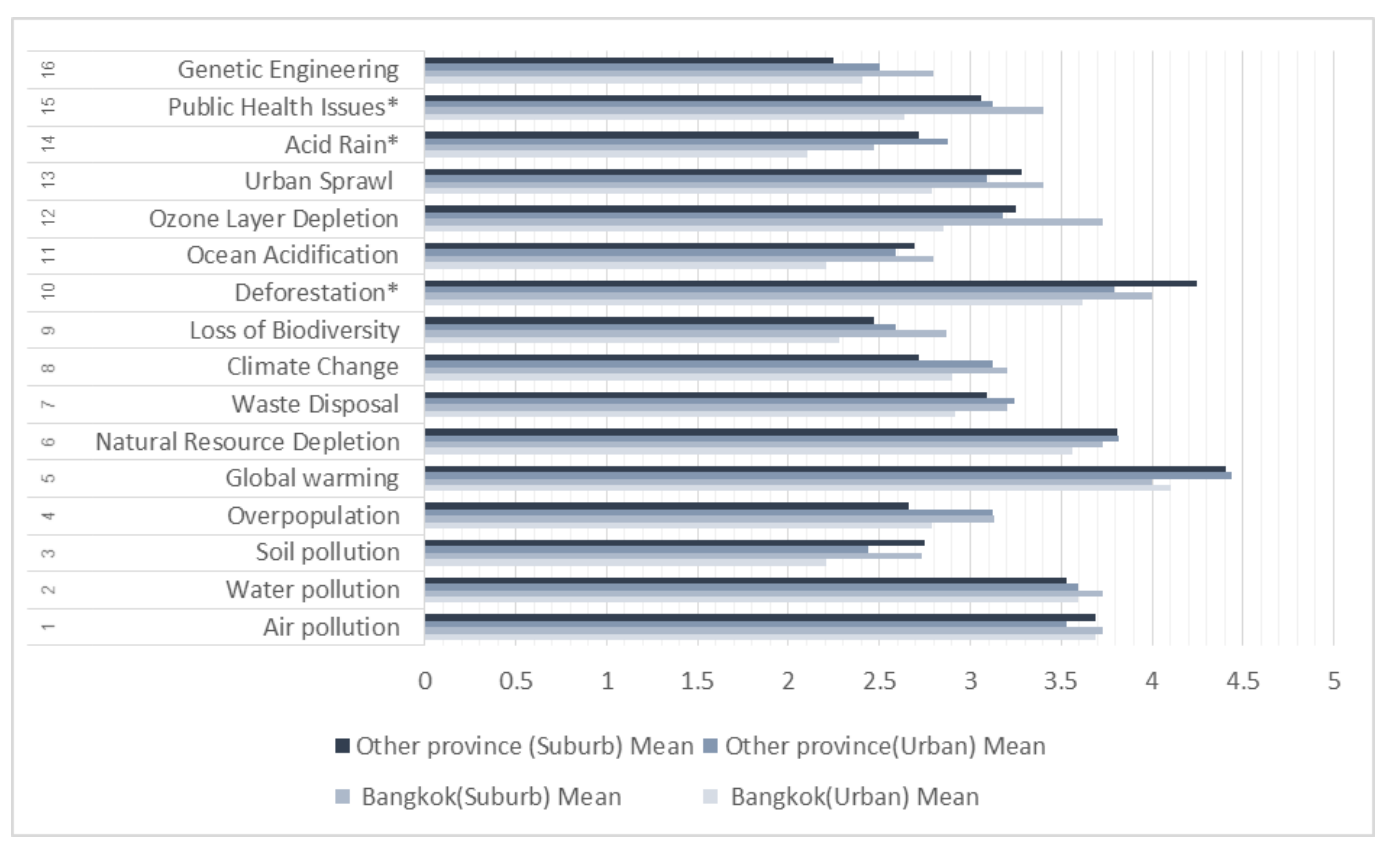

Fig. 5: Comparative data of hometown factor

\subsection{The factors of responsible for the cost of energy and perception of environmental issues}

Household energy expenses include electricity, water, gas, and fuel. The person responsible for the charge knows more about the costs and the amount of usability than those who are not responsible and may lead to differences in the perceived impact of the problem.

The test found no difference in 5 issues and it found differences in 11 issues, including Soil Pollution, Global warming, Natural Resource Depletion, Waste Disposal, Climate Change, Loss of Biodiversity, Deforestation, Ocean Acidification, Ozone Layer Depletion, Acid Rain and Genetic Engineering. The cost responsibility factor has a significant impact on the overall perception of environmental issues. Those who are responsible for all costs and paying some will tend to perceive problems in an average higher than those who are not responsible for the costs.

Table 7. Comparative data in the factors of responsible for the cost of household energy

\begin{tabular}{|c|c|c|c|c|c|c|}
\hline \multirow[t]{2}{*}{ Environmental problems } & \multicolumn{2}{|c|}{ Pay all group } & \multicolumn{2}{|c|}{ Pay some group } & \multicolumn{2}{|c|}{ Not pay group } \\
\hline & Mean & S.D. & Mean & S.D. & Mean & S.D. \\
\hline Air pollution & 3.92 & 1.00 & 3.79 & 0.74 & 3.55 & 0.98 \\
\hline Water pollution & 3.75 & 0.87 & 3.58 & 1.09 & 3.57 & 0.90 \\
\hline Soil pollution* & $2.33^{\mathrm{ab}}$ & 1.07 & $2.85^{\mathrm{a}}$ & 1.15 & $2.35^{b}$ & 1.20 \\
\hline Overpopulation & 2.83 & 1.53 & 2.85 & 1.18 & 2.92 & 1.31 \\
\hline Global warming* & $4.67^{a}$ & 0.65 & $4.45^{\mathrm{ab}}$ & 0.71 & $4.12^{b}$ & 0.96 \\
\hline Natural Resource Depletion* & $4.00^{\mathrm{ab}}$ & 1.48 & $4.18^{a}$ & 0.88 & $3.48^{\mathrm{b}}$ & 1.45 \\
\hline Waste Disposal* & $2.75^{a}$ & 1.29 & $3.58^{b}$ & 1.12 & $2.93^{\mathrm{ab}}$ & 1.31 \\
\hline Climate Change $^{*}$ & $3.92^{\mathrm{a}}$ & 0.79 & $3.24^{a}$ & 1.30 & $2.67^{b}$ & 1.09 \\
\hline Loss of Biodiversity* & $2.25^{\mathrm{ab}}$ & 1.54 & $2.94^{a}$ & 1.22 & $2.33^{b}$ & 1.22 \\
\hline Deforestation* & $3.75^{\mathrm{ab}}$ & 1.29 & $4.36^{a}$ & 0.74 & $3.69^{b}$ & 1.15 \\
\hline Ocean Acidification* & $2.92^{\mathrm{ab}}$ & 1.88 & $3.12^{a}$ & 1.60 & $2.19^{b}$ & 1.34 \\
\hline Ozone Layer Depletion* & $3.50^{\mathrm{ab}}$ & 1.73 & $3.64^{a}$ & 1.41 & $2.89^{b}$ & 1.48 \\
\hline Urban Sprawl & 3.58 & 1.24 & 3.33 & 1.11 & 2.89 & 1.40 \\
\hline Acid Rain* & $3.25^{a}$ & 1.76 & $2.94^{a}$ & 1.48 & $2.24^{b}$ & 1.38 \\
\hline Public Health Issues & 3.08 & 1.50 & 2.91 & 1.40 & 3.00 & 1.18 \\
\hline Genetic Engineering* & $2.92^{\mathrm{ab}}$ & 1.38 & $2.79^{a}$ & 1.43 & $2.21^{b}$ & 1.27 \\
\hline
\end{tabular}

*Significant 0.5

a b ab shows different or not different between each group 


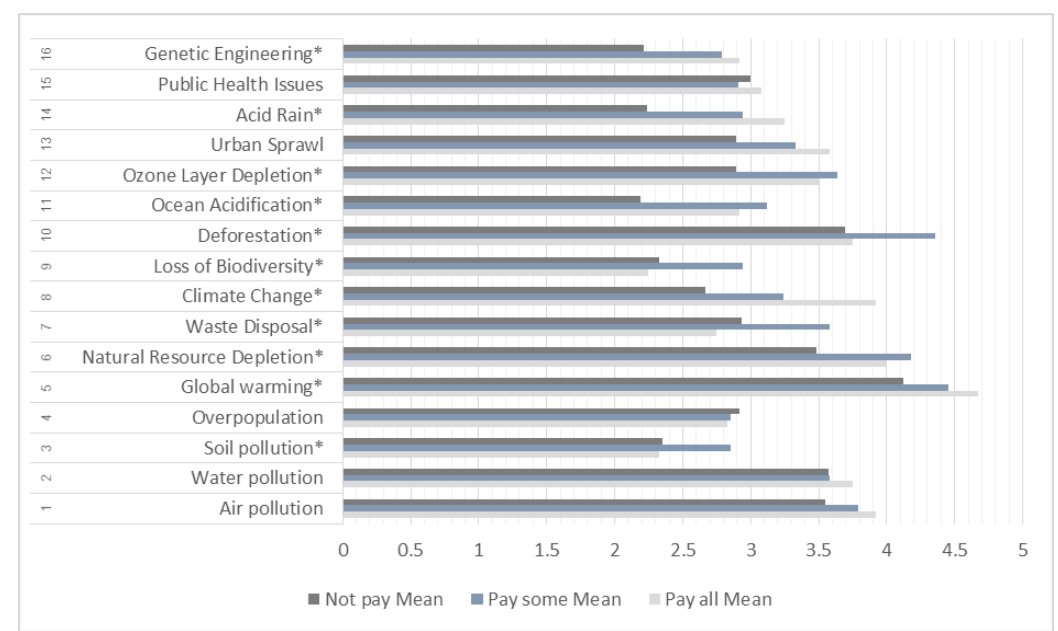

Fig. 6: Comparative data in the factors of responsible for the cost of household energy

\subsection{Residential area factor and perception of environmental issues}

In the study, we expect urban residents to perceive urban environmental issues to be of a higher degree than urban and non-urban dwellers. The residents outside the city to perceived environmental problems occurring outside the city better.

The statistic showed no significant difference are in 15 issues and found a difference in Deforestation. The results of the study found that the problem in just outside the city. Non-urban dwellers can see the condition. Overall, urban and non-urban dwellers do not differ in their perceptions of environmental problems either in urban or urban areas or independent problems. The samples tend to perceive in the same direction. Out-of-town residents have a higher perception of problems than urban dwellers.

Table 8. Comparative data in Residential area factor

\begin{tabular}{|c|c|c|c|c|}
\hline \multirow[t]{2}{*}{ Environmental Issues } & \multicolumn{2}{|c|}{$\begin{array}{c}\text { urban } \\
\text { area } \\
\text { resident }\end{array}$} & \multicolumn{2}{|c|}{$\begin{array}{c}\text { Rural } \\
\text { Area } \\
\text { resident }\end{array}$} \\
\hline & Mean & S.D. & Mean & S.D. \\
\hline $\begin{array}{l}\text { Air pollution } \\
\text { Water poilution } \\
\text { Soil pollution } \\
\text { Overpopulation } \\
\text { Waste Disposal }\end{array}$ & $\begin{array}{l}3.62 \\
3.59 \\
2.32 \\
2.93 \\
3.08\end{array}$ & $\begin{array}{l}0.95 \\
0.96 \\
1.14 \\
1.30 \\
1.34\end{array}$ & $\begin{array}{l}3.70 \\
3.59 \\
2.74 \\
2.83 \\
3.11\end{array}$ & $\begin{array}{l}0.89 \\
0.93 \\
1.24 \\
1.29 \\
1.20\end{array}$ \\
\hline Urban Sprawl & 2.92 & 1.40 & 3.35 & 1.16 \\
\hline Environmental lssues & \multicolumn{2}{|c|}{$\begin{array}{l}\text { urban } \\
\text { area } \\
\text { resident }\end{array}$} & \multicolumn{2}{|c|}{$\begin{array}{c}\text { Rural } \\
\text { Area } \\
\text { resident }\end{array}$} \\
\hline Rural problems & Mean & S.D. & Mean & S.D. \\
\hline Natural Resource Depletion & 3.70 & 1.42 & 3.76 & 1.25 \\
\hline Loss of Biodiversity & 2.41 & 1.31 & 2.63 & 1.22 \\
\hline Deforestation* & 3.69 & 1.18 & 4.20 & 0.88 \\
\hline Ocean Acidification & 2.36 & 1.45 & 2.76 & 1.62 \\
\hline \multicolumn{5}{|l|}{ Independent problems } \\
\hline Global warming & 4.27 & 0.90 & 4.26 & 0.88 \\
\hline $\begin{array}{l}\text { Climate Change } \\
\text { Ozone Layer Depletion } \\
\text { Acid Rain } \\
\text { Public Health Issues } \\
\text { Genetic Engineering }\end{array}$ & $\begin{array}{l}3.00 \\
3.01 \\
2.45 \\
2.84 \\
2.45 \\
\end{array}$ & $\begin{array}{l}1.23 \\
1.52 \\
1.48 \\
1.19 \\
1.38\end{array}$ & $\begin{array}{l}2.87 \\
3.39 \\
2.67 \\
3.22 \\
2.43 \\
\end{array}$ & $\begin{array}{l}1.15 \\
1.48 \\
1.51 \\
1.36 \\
1.31\end{array}$ \\
\hline
\end{tabular}




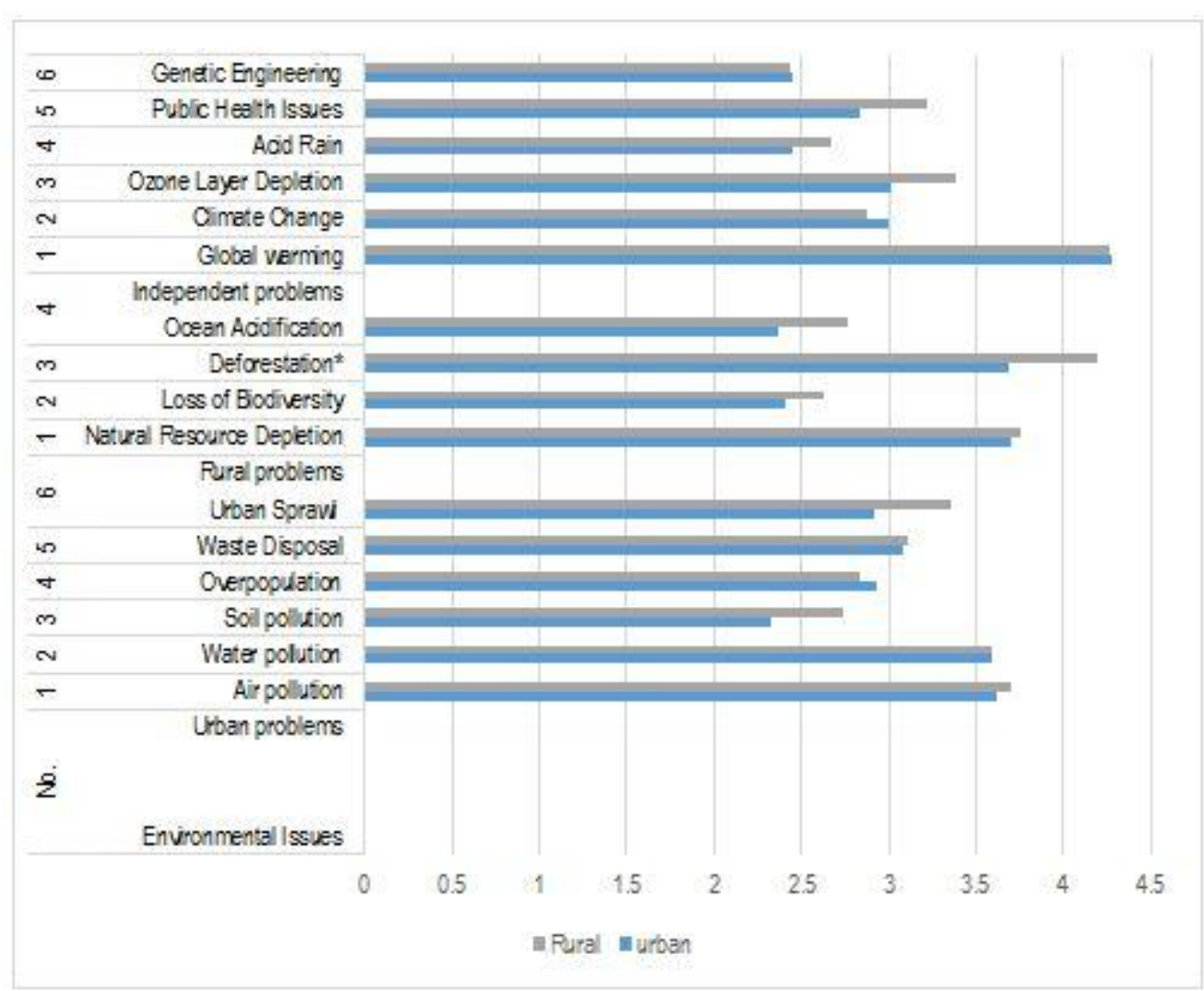

Fig. 7: Comparative data in Residential area factor

\subsection{Discussions}

This research is a study of environmental behaviour in environmental perception issues which brings different aspects of personal factors and were tested using statistical methods. The study of variable dimension can be grouped as follows:

- Personality or individual factor dimension: gender and age, There is not sufficient evidence to identify the difference in perceptions that consistent with Liere and Dunlap's study (1980). It cannot explains environmental problem perception from factors.

- Environment or Place attachment factor dimension: Accommodation characteristics, hometown and residential area, the result of this research found the significances of the perception of some problems such as Waste Disposal and Urban Sprawl in nature of accommodation factor

- Economic or social class factor dimension: income and responsibility, factor is very sensitive was found that these two factors are related to the living conditions, the well-being of the person's social and afford in media of environmental information.

This research is a part of the research on "Product Design Enhancing Perception and Encouraging Behavioral Change Perception and Encouraging Behavioral Change to Sustainability" (Tunprawat, Rugwongwan and Singhirunnusorn, 2017) to study the factors affecting the perception of environmental issues which connect to the product design theory. The limitation of this study are the diversity and sample size, which also require different sample data collection. In the next step, this research conducts studying in multidimensional studies such as attitudes, awareness and knowledge connect to environmental perception and encouraging behavioral change.

\section{Acknowledgements}

The authors would like to acknowledge Rajamangala University of Technology Phra Nakhon for funding

\section{References}

Abraham, J., \& Rufaedah, A. (2013). Pro-Environment Being and Ecological Attachments. Journal of ASIAN Behavioural Studies, 3(13), 55-62.

Gibson, J. J. (1950). The perception of the visual world. Oxford, England: Houghton Mifflin. 
Gifford, G., \& Nilsson, A. (2014). Personal and social factors that influence pro-environmental concern and behaviour: A review. International Journal of Psychology, 49(3), $141-157$.

Intergovernmental Panal on Climate Change (IPCC). (2013). Climate Change 2013 The Physical Science Basis. NY, USA: Cambridge University Press.

Iversen, H., \& Rundmo, T. (2002). Environmental concern and environmental behaviour among the Norwegian public. Journal of Risk Research, 5(3), 265-279.

Kaman, L., (2009). Gender differences in Hong Kong adolescent consumers' green purchasing behavior. Journal of Consumer Marketing, 26(2), 8796. https://doi.org/10.1108/07363760910940456

Kollmuss, A., \& Agyeman, J. (2002). Mind the Gap: Why do people act environmentally and what are the barriers to pro-environmental behavior. Environmental Education Research, 8(3), 239-260.

Krajhanzl, J. (2010). Environmental and Proenvironmental Behavior in School and Health 21. Health Education: International Experiences, editor Remulka, E., Bruno Press, pp. 251-274.

Kukreja, R., (2017). 15 Major Current Environmental Problems. Retrieved March 2, 2017, from http://www.conserve-energy-future.com/15-current-environmentalproblems.php

Liere, K.D.V. \& Dunlap, R.E.(1980). The Social Bases of Environmental Concern: A Review of Hypotheses, Explanations and Empirical Evidence. The Public Opinion Quarterly, 44(2), 181-197.

Tunprawat, C., Rugwongwan, Y., \& Singhirunnusorn, W., (2017) Product Design Enhancing Perception and Encouraging Behavioral Change Perception and Encouraging Behavioral Change to Sustainability. Environment-Behaviour Proceedings Journal, 2(5), 355-362.

United Nations. (2013). World Population Prospects the 2012 Revision, New York, USA: United Nations.

Wichitra, S., Kidanun D., \& Warapon, K. (2012). Household Recycling Behaviours and Attitudes toward Waste Bank Project: Mahasarakham Municipality. Journal of ASIAN Behavioural Studies, 2(6), 35-47.

Yusof, Z.B.BT. \& Jamaludin, M. (2015). Green Practices of Small Island Chalet Operators in East Peninsular Malaysia. Procedia - Social and Behavioral Sciences, 202, 340-350. 